\title{
Uterine Corpus Carcinoma pT1b TNM
} Finding v7

National Cancer Institute

\section{Source}

National Cancer Institute. Uterine Corpus Carcinoma pT 1b TNM Finding V7. NCI

Thesaurus. Code C89562.

Uterine corpus carcinoma with tumor invading one-half or more of the myometrium.

(from AJCC 7th Ed.) 